\title{
Internet Practices of Turkish Youth
}

\section{Prof.Dr. Filiz Aydogan Boschele}

Department of Communication

Marmara University, Istanbul, Turkey

\section{Doi:10.5901/jesr.2013.v3n7p374}

\begin{abstract}
Turkey ranks 7th in Europe and 13th in the world in Internet use. As a non-hierarchical realm, internet, instead of enabling individuals a limitless space for movement, has become an area where surveillance and supervision have become obvious and freedoms are constrained. The first section of this study examines the Internet experience in Turkey where users are aware that they are being monitored and have feelings of dismay while browsing the Internet. It will address the reason of delay of the arrival of communication technologies to Turkey, starting from the printing houses operated under the governance of government 200 years after the West, the relation to this situation of surveillance and with Turkey's tradition of democratization and politics. The second section deals with the emergence and legitimatization of Internet in Turkey as an underdeveloped country. Arguing that the Internet and new technologies encompass utopian and dystopian aspects in one pot, the last section will point towards a survey on attitudes of university student users. Thus, Turkish people's opinions on surveillance and prohibition will be manifested. The the study will strive to provide insight to the dilemma between Internet's liberalization, democratization and surveillance potentials within the context of Turkish society.
\end{abstract}

\section{Introduction}

Many authors today stress that internet is the most powerful tool with the potential to change the way the democracy is implemented thanks to its nature open to participation and interaction. Moreover, the interaction feature of internet provides the opportunity to emerge as a new "public sphere" suitable to the public sphere of $18^{\text {th }}$ century as stated by Habermas. Indeed, internet provides direct socialization for all citizens, enabling them to establish relationships within the public sphere, ensuring them to be creative and providing them with the opportunity to focus on their own areas of interest. In this regard, internet is considered as the new power of democratization. Therefore, internet as an advanced mass communication form used by the highest number of participants is a kind of medium deserving to be protected against governmental interventions.

Today, generally speaking the youth receives better education compared to prior periods, particularly, it has more technological opportunities compared to before. Thanks to the transformation of virtually all parts of daily life by new communication technologies, today's youth are called the Net Generation. Turkey has a large young population, which correspond to $50 \%$ of its entire population, Turkey's population in 2007 was 70 million 586 thousand 256, is in the age group of 28 and younger. Findings in 2007 showed that young people preferred reading books in their leisure times, however, in 2009, this study shows that they prefer to spend time in their rooms, on their computers, connected to online social networks. According to the Turkish Statistical Institute, in 2007 only $18.94 \%$ of the young population had the opportunity to access internet from their home. The highest group of internet users is between 16 and 24 , which roughly constitutes Turkish youth. This study seeks to determine how and for which purposes Turkish young people are using these rapidly developing new technologies and what is their opinion about them.

The first section of this paper will address the reason of delay of the arrival of communication technologies to Turkey, starting from the printing houses under the government 200 years after the West.. The second section deals with the relation between internet and young people in Turkey. And finally, with an empirical study which consists of a series of open ended individual interviews conducted with 24 university students sharing their internet experience, it attempts to understand how and for which purposes Turkish youths use the internet.

\section{A Brief History of Communication Technologies in Turkey}

The printing press was established in 1450s in Europe. In 1500, after 50 years, the number of printed books in Europe reached around 40 thousand. However, in the Ottoman Empire at that time, the sultan Sultan Beyazıt II in 1485, 
prohibited the practice of printing. Selim I imposed this prohibition again in 1515. The first books in Arabic were published in early $16^{\text {th }}$ century, not in Ottoman Empire, but in Europe. The founder of the first official printing press and the first person to publish in the Ottoman Empire was İbrahim Müteferrika. He could only start to operate his printing house in 1729, nearly 281 years after its invention, upon the fatwa of Sheikh Al-Islam and royal decree of the sultan. (Belge, http://www.radikal.com.tr/haber.php?haberno=10966,28.06.2010).

Thereafter, the Jewish having escaped from the persecution and being accepted to the Ottoman territories in 1492 by Sultan Beyazıt II, introduced the printing technique to the Ottomans. David and Samuel ibn Nahmias, two brothers, founded the first printing house in Istanbul only one year after their arrival in the Ottoman Empire. However, they only obtained consent for printing the Old Testament and religious books and thus, the books printed in the Ottoman Empire in this period were just the Old Testament, prayer books and books on history of religions. Even some Muslims attempted a number of times to establish printing houses in the Ottoman Empire but they were always rejected and it was stressed that even the uran should be written manually as in old times. (http://www.sirince.net/modules.php?name $=$ News\&file=article\&sid=725, 29-06.2010).

Like the establishing of printing houses, processes leading to the realization of media in Turkey differ from those in the Western world. Advancements in Turkey were realized through political dynamics and governmental initiatives contrary to the Western world where economical and social dynamics had a prominent role. The first newspaper in Turkish was published by the state in order to act as a method leading to the Westernization of society. That is why Turkish media has a unique nature when compared with similar organizations of the West and the impact of the state felt at the time of its emergence has always followed the Turkish media throughout its history. In 1930s Turkey witnessed the strict ideological practices of single party regime while totalitarian regimes ruled the West. In the 1950s and afterwords, the Western world experienced the reigime of liberal democracy and also Turkey enjoyed more liberal regulations and practices. Freedom of the press also took on different shapes within this framework. New conservative policies were implemented in the USA and Europe during 1980s and 1990s coinciding with the fall of socialism. During these same years in Turkey, political, economical and social impacts of this change were felt and commercialization in media witnessed its strengthening. (VedatDemir,http://www.koprudergisi.com/index.asp?Bolum=EskiSayilar\&Goster=Yazi \&YaziNo=956).

Unlike the advancements regarding the printing press introduced to Turkey almost 280 years after its invention, radio broadcasting was not very late when compared with the rest of the world. First radio programs were broadcasted at the beginning of the 1920s in the world and on May 6, 1927 in Turkey. The Television, just like the radio, was introduced in Turkey at an earlier time. TRT Ankara Television performed first test broadcasts on January $31^{\text {st }}$ of 1968 . State monopoly dominated the development of radio-television broadcasting in Turkey for a long period just like the media. In this regard, the model of radio-television broadcasting in Turkey had been just public broadcasting until 1993. Monopoly of radio and television broadcasting in Turkey maintained as a monistic model was abolished with a Constitutional amendment in 1993, a Law No. 3984 passed in 1994 and instead a "competitive model" was adopted. A number of private radios and televisions were established (Isbir 2007: 820) and today television is the most common medium across Turkey with $97 \%$ of households.

It was, on the other hand, in 1993 when internet was introduced to Turkey. Turkish Universities and Research Institutes Network founded under the leadership of Ege University were the first to introduce internet technology in 1987. Turkey became acquainted with internet on April 12, 1993 thanks to the connection established between Ankara and Washington with a line rented. Thus, April 12 was declared as the birthday of internet in Turkey.

ODTU (Middle East Technical University) and Bilkent University launched the first Turkish websites in the same year and in 1994, organizations and firms were granted with internet accounts. In 1996, first internet infrastructure of Turkey - TURNET - became operational. As late as 1997, it was estimated that nearly 30,000 PCs had internet connections in Turkey. Internet became widespread in 2003 and number of internet users reached 30 million in 2009 from 7 million in 2003(http://www.internetarsivi.metu.edu.tr/tarihce.php, 30.06.2010). In 2013, \%47 percent of Turkish population has internet access.

\section{Internet and Turkish Youth}

Many new scholars interested in media today share the same opinion that internet is the most appropriate medium complying with the definition of public sphere by Habermas. These scholars mention that interaction feature of internet and uniqueness of hypertext feature render internet as a "public sphere" complying with the public sphere model of $18^{\text {th }}$ century. So much so that internet is considered as the new power of democratization in this regard. Indeed internet may 
provide direct socialization for all citizens, enabling them to increase the number of their relationships within the social sphere, ensuring them to be creative and providing them with the opportunity to focus on their own areas of interest. Thus, internet considered as an advanced mass communication form used by the highest number of participants deserves protection against state intervention. (Hirschkop, 2003:246).

According to optimistic accounts, the internet provides new opportunities for self-expression, sociability, community engagement, creativity and new literacy. Critical theorists argue that youth content will oppose and reverse the traditional dominance of consumers by producers and will facilitate a new 'peer culture' among young people, both locally and globally (Livingstone, 2008:394). Sonia Livingstone's recent studies on the relationship between youth and internet argues that children spend less time in front of the television than before and they use internet for playing, learning and consuming. As far back as 1999 two-thirds of UK children and teenagers had a television in their bedroom and over half of UK homes with children had at least one personal computer with Internet access. Overall, 6 to 17 years old individuals were spending some five hours per day with the media. In the United States, she obtained similar findings of five and a half hours per day with the media. To these figures it must be added the introduction of faster internet connections which improved the performance of personal computers. This is a considerable investment of time, indicating children and young people's priorities and preferences, as well as the limits of the leisure choices available to them (Livingstone and Bovill, 1999:154).

According to the Research for Use of Information Technologies by Households in 2009, conducted by the Turkish Statistics Institute, $40 \%$ of the houses have the facility of internet access. In the period between January and March 2009 , computer and internet usage rates of household members in the age group between 16 and 24 was $62.2 \%$. In the same period, of the household members using internet, $25.50 \%$ used it at least once a week whereas $61.11 \%$ used it almost everyday. The age group with the highest rate of computer and internet usage is 16-24. This group is followed by the age group of 25-34. The highest computer and internet usage rates by educational status is in higher education school and above with $88.5 \%$ and $72.4 \%$ of the students using a computer and the internet. (http://www.tuik.gov.tr NeriBilgi.do?tb_id=60\&ust_id=2, 09.09.2009).

In Turkey, a great proportion of the youth goes to internet cafes. What is interesting is thatmore than half of those going to internet cafes have computer or internet connection at home. Many researches have revealed that the young users in internet cafes comprise mainly the segments with low socio-economical level. However, young people prefer using computer in these places rather than in their homes because they are together with their friends and because it is more convenient. According to a research conducted by Sakarya University, a great part of the internet café users are males aged between 12 and 25, including high school and university students. In the interviews conducted to identify what was behind using internet cafes they mostly used words "habit", "seeing friends", " a place for meeting", "fun", "enjoyment". They expressed that they mostly go to play games on the internet, secondly for using MSN and e-mail, the third for research, and the fourth as chat and doing homework http://www.ensonhaber.com/Teknoloji/29288/nedeninternet-cafe-tercih-ediliyor.html, 14.09.2009).

\section{A Qualitive Research onTurkish Youth Internet Practices}

Results of a digital survey conducted in 2009 with the participation of 1948 people providing information on the status of internet users in Turkey revealed that 49.5 percent of the participants spent each day over 5 hours in average on internet and 25.1 percent were online for more than 50 hours a week. Out of 91.3 percent of internet users being online mainly for chatting, 48 percent stated that they made use of this service when they had the opportunity, 20 percent in the evenings and 16.6 percent continuously. According to the results of the survey, internet was not just used for chat but used also for homework, listening to and downloading music, downloading and streaming movies and making new friends. (http://www.marketingturkiye.com/yeni/Haberler/NewsDetailed.aspx?id=14532, 29.11.2009).

According to results of the "Research on Use of Computers and Relevant Behaviors in Turkey", users made use of internet primarily for the purposes of "listening to/downloading and purchasing music". Same research also revealed that internet was used for "sending and receiving e-mails", "surfing on the websites" as the third preference and "chatting" as the fourth preference. Individuals not using computers, on the other hand, stated that if they were to have computers one day, they would attach same levels of importance to education (59.7\%), music (61\%) and photographs/videos (62.4\%).(http://www.digitalage.com.tr/Haber/turkiyenin-dijital-gundemi-egitim/3d50174f-fa62-4286-8f11-134c06d222f7 .aspx, 06.11.2009). However, in Turkey, internet is restricted by laws, in other words, controlled by state just like the other mediums in their first years.

A part of the study, the purposes of internet usage of Turkish youth are being determined through the use of focus 
group discussion which is a qualitative research method. The main group is composed of students of communication which most probably will be the employees of media industry in the future. Sample group forming the focus group is designated to be 2 groups consisting of 12 students from the students of Marmara and Istanbul Universities. But the results of the focus group cannot be attributed to the whole main group due to the insufficient numbers as in quantitative studies. The research, carried out under the supervision of a moderator, took 2,5 hours. Following are the conclusions within the scope of the research.

The purpose of this study is to reveal internet practices of Turkish youth. This study covers 12 female and 12 male students from the faculty of communications at the age of 18 to 22. They all have internet access at home. These youngsters stated that they used internet for social relations, chatting, listening to music, playing games and doing their homework as suggested by them in the order of priority.

- They also told that they were subscribers of 1 to 3 different social websites and in parallel; they had different profiles as many as their number of subscriptions. They mentioned that they visited these social media at least once a day and spent 3 to 5 hours on these media.

- According to these youngsters social media is their first habit of spending their free times and among these networks they used Facebook. Twitter and YouTube the most and these networks provided them with personal areas and that was primarily why they were interested a lot in these networks.

- $\quad$ Furthermore, they told that they mostly chat, looked at other profiles, shared the things they liked, played games, sent each other messages, and communicate with people they had common areas of interest as suggested by their order of preference.

\section{Graphic 1:}

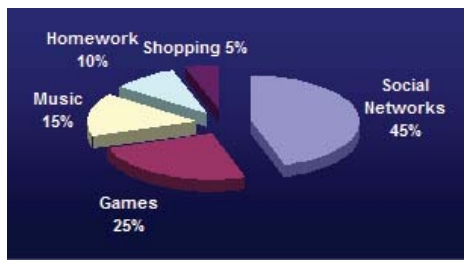

The interviewees stated that they use the internet for social interaction, playing games, listening to music, help with their homework, and finally, for shopping.

According to the research findings, the social network mostly used is Facebook with $47 \%$. While twitter is second with $24 \%$, YouTube is the third with $14 \%$, Instagram is the fourth, and Blogs are the fifth. They use internet mostly for social relations.

\section{Graphic 2:}

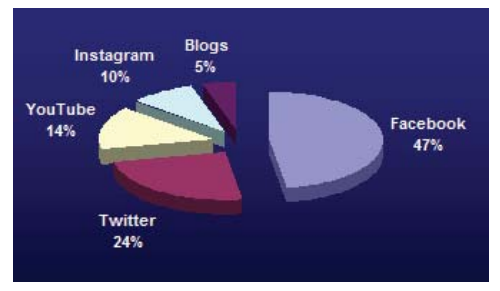

When it is asked why they preferred the sites involving social interaction such as Facebook and Twitter, they indicated that they regard Facebook as "a social friendship site". They tell that they socialize with these sites, get information about their old friends, share photos, and playing games. What's more, in Turkey, Facebook, with about 45 million users worldwide, has turned into a virtual identity data, as the interpreter of the relations which the young people could not establish and the words which they cannot say in daily life. In other words, Facebook has been defined as a space helping young people to say "I'm here, too" and a space for "being able to socialize in virtual world". 


\section{Graphic 3:}

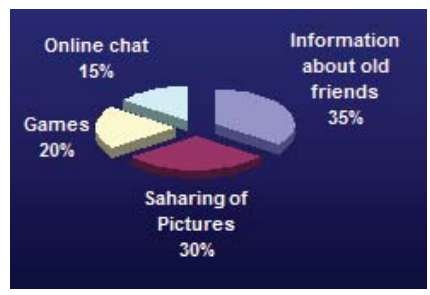

\section{Conclusion}

As we see from this study, all students have computer and internet connection in their rooms. When considered from the aspect of having internet facilities, it wouldn't be wrong to say that Turkish youth adapt the information age in a short time. The subjects spend most of their times on the internet for social networks like Twitter and Facebook rather than doing research or getting information. While the virtual media comes into prominence as a research and information tool, unfortunately, it is rather preferred for chat and games in Turkey.

From a competitive capitalism age theorized by Marx, a monopolist capitalism age criticized by Frankfurt School in the 1930s, we entered as Dauglas Kellner pointed out into a "techno-capitalism" age which incorporates the capital, technology, information and entertainment industries. In this techno-capitalism age, we live in technology gradually gains importance for the youth, just like for virtually everybody. However, the youth use the technology as social interaction tool rather than an opposition tool against the imposed system. The internet which provides an unlimited action opportunity to the youth as a space without hierarchy is unfortunately used as a "un-memorization and oblivion" tool for the young*.

\section{References}

Belge,Murat."Matbaanın Icadını Icad Etmek", http://www.radikal.com.tr/haber.php?haberno=10966, 28.06.2010.

Demir,Vedat. "Türk Medyası ve Demokrasi", Köprü, http://www.koprudergisi.com/index.asp?Bolum=EskiSayilar\&Goster =Yazi\&YaziNo=956, 28.06.2010.

Hirschkop, Ken(2003). "Demokrasi ve Yeni Teknolojiler". Kapitalizm veEnformasyon Çağı, Der. Robert W. McChesney-Ellen Meikins Wood- John Bellamy Foster. Çev: Nil Sinem Çanga,Erhan Baltacı, Özge Yalçın. Ankara: Epos. pp. 241-251.

Işbir, Begüm, (2007), "Kamu Hizmeti İlkeleri Işığında Özel Radyo-Televizyon Yayıncılığının Değerlendirilmesi”, Gazi Üniversitesi Hukuk Fakültesi Dergisi, Vol:XI, No:1-2, pp.815-835.

Livingstone, S. and Bovill, M. (1999). Young People, New Media: Report of the Research Project: Children, Young People and the Changing Media Environment. London : London School of Economics and Political Science.

Livingstone, Sonia (2008). "Taking Risky Opportunities in Youthful Content Creation: use of social networking sites for intimacy, privacy and self-expression", New Media and Society. Vol.10. Number 3. pp. 393-411.

Oskay, Ünsal(1998). Yıkanmak İstemeyen Çocuklar Olalım. Yapı Kredi Publication. http://www.digitalage.com.tr/Haber/turkiyenin-dijitalgundemi-egitim/3d50174f-fa62-4286-8f11-134c06d222f7.aspx, 06.11.2009.

http://www.marketingturkiye.com/yeni/Haberler/NewsDetailed.aspx?id=14532, 29.11.2009.

RTUK (2006). İlköğretim Çocuklarının Televizyon İzleme Alışkanlıkları Kamuoyu Araştırması, http://www.rtuk.org.tr/sayfalar /IcerikGoster.aspx?icerik_id=0f157d78-0884-47d4-9591-3efc39178e05, 09.09.2009).

http://www.tuik.gov.tr/VeriBilgi.do?tb_id=60\&ust_id=2, 09.09.2009.

http://www.ensonhaber.com/Teknoloji/29288/neden-internet-cafe-tercih-ediliyor.html, 14.09.2009.

http://www.sirince.net/modules.php?name=News\&file=article\&sid=725,29.06.2010.

http://www.internetarsivi.metu.edu.tr/tarihce.php, 30.06.2010.

${ }^{*}$ This paper was written before Occupygezi Movement in 2013 June. 